\title{
Protein and Glycoprotein Patterns Related to Morphogenesis in Horseradish Tissue Culture
}

\author{
Petra Peharec Štefanić, ${ }^{a}$ Ana Smolko, ${ }^{a}$ Anita Horvatić, ${ }^{b}$ Mario Cindrić, ${ }^{b}$ \\ Marijana Krsnik-Rasol, and Biljana Balen ${ }^{\mathrm{a}, *}$ \\ ${ }^{a}$ Department of Molecular Biology, Faculty of Science, University of Zagreb, \\ Horvatovac 102a, HR-10000 Zagreb, Croatia \\ ${ }^{\mathrm{b}}$ Ruđer Bošković Institute, Bijenička cesta 54, HR-10000 Zagreb, Croatia
}

\begin{abstract}
In this study cellular proteins of in vitro grown horseradish (Armoracia lapathifolia Gilib.) tissues of different morphologies, leaves (L), teratoma (TM) and tumor (TN), were separated by one-dimensional (1-DE) and two-dimensional polyacrylamide gel electrophoresis (2-DE) in order to reveal developmentally specific proteins. Moreover, proteins were subjected to analyses by lectin assays to reveal whether the morphological differences were reflected in protein glycosylation. 1-DE glycoprotein pattern showed substantial distinctions between horseradish tissues of different morphologies, which was in contrast to silver stained protein profiles, where only slightly qualitative changes were observed. 2-DE revealed more differences in expression of cellular proteins between examined tissues in comparison to 1-DE, while 2-DE blots confirmed quantitative difference in expression of $43 \mathrm{kDa}$ glycoprotein between investigated tissues. Mass spectrometry analysis identified this protein as a typical horseradish peroxidase. Obtained results imply that the oligosaccharide structures could be important determinants of specificities of horseradish tissue morphology. (doi: 10.5562/cca2078)
\end{abstract}

Keywords: morphogenesis, horseradish, glycoproteins, lectine assay, tissue culture, 2-DE

\section{INTRODUCTION}

Before becoming functional, most of the proteins that are translated from mRNA in eukaryotic cells undergo chemical changes, which are known as posttranslational modifications. The nascent or folded proteins, which are stable under physiological conditions, are subjected to a battery of specific enzyme-catalyzed modifications on the side chains or backbones. Posttranslational modifications play a crucial role in generating the heterogeneity in proteins and also help in utilizing identical proteins for different cellular functions in different cell types. How a particular protein sequence will act in most of the eukaryotic organisms is regulated by these modifications. Proteome diversification by covalent modification occurs in prokaryotes but is much more extensively encountered in nucleated cells, both in terms of types of modifications and frequency of occurrence. About $5 \%$ of the genomes of higher eukaryotes can be dedicated to enzymes that carry out posttranslational modifications of the proteomes. ${ }^{1}$

Glycosylation of proteins is one of the most frequent posttranslational modifications. Carbohydrate binding to a polypeptide chain has a great impact on physicochemical properties of proteins such as its resistance to thermal denaturation, protection from proteolytic degradation and solubility and thus, glycosylation can change basic biological protein functions including imunogenicity, specific activity, and the ligand-receptor interaction. A single protein site can be occupied by a number of glycan structures, and this gives rise to extremely heterogeneous glycoprotein populations, called glycoforms. The glycosylation pattern of a glycoprotein is, however, not random but dependent on the cell type and physiological conditions. ${ }^{2}$

The oligosaccharide chain can be either $N$ - or $O$ linked. $\mathrm{N}$-glycosylation is the most studied of the glycosylation events and it happens in a very similar manner in animal and plant cells. ${ }^{3}$

Only a few studies have been conducted to reveal the impact of environmental and developmental changes on protein $\mathrm{N}$-glycosylation in plants. It has been shown that changes in protein $\mathrm{N}$-glycosylation follow morphogenic events. ${ }^{4}$ Analysis of these changes can allow an insight in glycosylation level, which is specific for a certain developmental stage. Stevens et $a l^{5}$ reported that

\footnotetext{
* Author to whom correspondence should be addressed. (E-mail: bbalen@zg.biol.pmf.hr)
} 
the glycosylation profile of endogenous proteins can be altered by plant development and growth conditions. The analysis of $N$-linked glycans of soluble glycoproteins from leaves of tobacco plants of different age and grown under different growth conditions demonstrated that developmental processes in plants could influence glycosylation. ${ }^{6}$ However, relatively little is known about the effects of environmental conditions and developmental stage on proteins produced in plant tissue culture. It has been documented that in vitro cultured cell lines and tissue cultures from various origins exhibit changes in glycan formation that are correlated to changes in nutrient medium. ${ }^{7}$ Moreover, it was found that $N$-glycosylation of extracellular proteins ${ }^{8,9}$ as well as cellular proteins ${ }^{10,11}$ varies with the developmental stage and organization level of plant tissues cultured in vitro. Nevertheless, only modest information about the $N$-glycoprotein patterns related to cell differentiation, dedifferentiation, and transformation in tissue culture is available so far.

$O$-linked glycosylation is a form of posttranslational modification that occurs in the GA. Plant and mammalian $O$-glycans are usually considered as structurally different. ${ }^{12}$ The main $O$-glycosylated proteins in plants, extensins (EXTs) and arabinogalactan proteins (AGPs), belong to a large group of glycoproteins known as Hyp-rich glycoproteins (HRGPs). ${ }^{13}$ The role of $O$ glycosylation in growth and development of plant cells is even less studied than $\mathrm{N}$-glycosylation. Johnson et $a l .{ }^{14}$ reported that AGPs are likely to be important during plant development and in response to abiotic stress. Moreover, AGPs are known to have a role in embryogenesis; they have been identified in the culture medium supporting somatic embryogenesis in many plant species. $^{15-18}$ It was found that correct $O$-glycosylation on EXTs is essential for cell-wall self-assembly and, hence, root hair elongation in Arabidopis thaliana. ${ }^{19}$
In this study three different horseradish (Armoracia lapathifolia Gilib.) tissue types grown in vitro were analyzed. Horseradish plantlets were maintained during the long term (16 years) in vitro culture. ${ }^{20}$ Leaf explants of these plantlets were infected with Agrobacterium tumefaciens to induce crown-gall tumors. Obtained transformed tissue grew either as an unorganized tumor (TN) or as a teratogenous tumor, namely teratoma (TM). ${ }^{21,22}$ Cellular proteins of plantlets leaves (L) as well as of TM and TN tissues were separated by one-dimensional (1-DE) and two-dimensional polyacrylamide gel electrophoresis (2-DE) in order to reveal proteins specific for each tissue morphology. Moreover, protein extracts were subjected to analyses by lectin assays to reveal whether the morphological differences were reflected in glycosylation of cellular soluble proteins in horseradish tissues.

\section{EXPERIMENTAL}

\section{Plant Material}

Horseradish plantlets and transformed tissues were grown in vitro on a solid $\mathrm{MS}^{23}$ nutrient medium without any growth regulator under following culture conditions: $24{ }^{\circ} \mathrm{C}$, 16-h light/8-h dark period and irradiation of $33 \mu \mathrm{mol} \mathrm{m} \mathrm{m}^{-2} \mathrm{~s}^{-1}$. Plantlets were propagated by formation of light-induced buds on root fragments (Figure 1A). Transformed tissues were obtained after the leaf fragments (L) of horseradish plantlets were infected with a wild octopine-strain B6S3 of Agrobacterium tumefaci-ens. After the transformation primary crown gall tumor was obtained. During the subcultivation, from the primary tumor two phenotypically different transformed tissue lines were established: organized teratoma line (TM) (Figure 1B) and unorganized tumor line (TN) (Figure 1C). The TM tissue produced

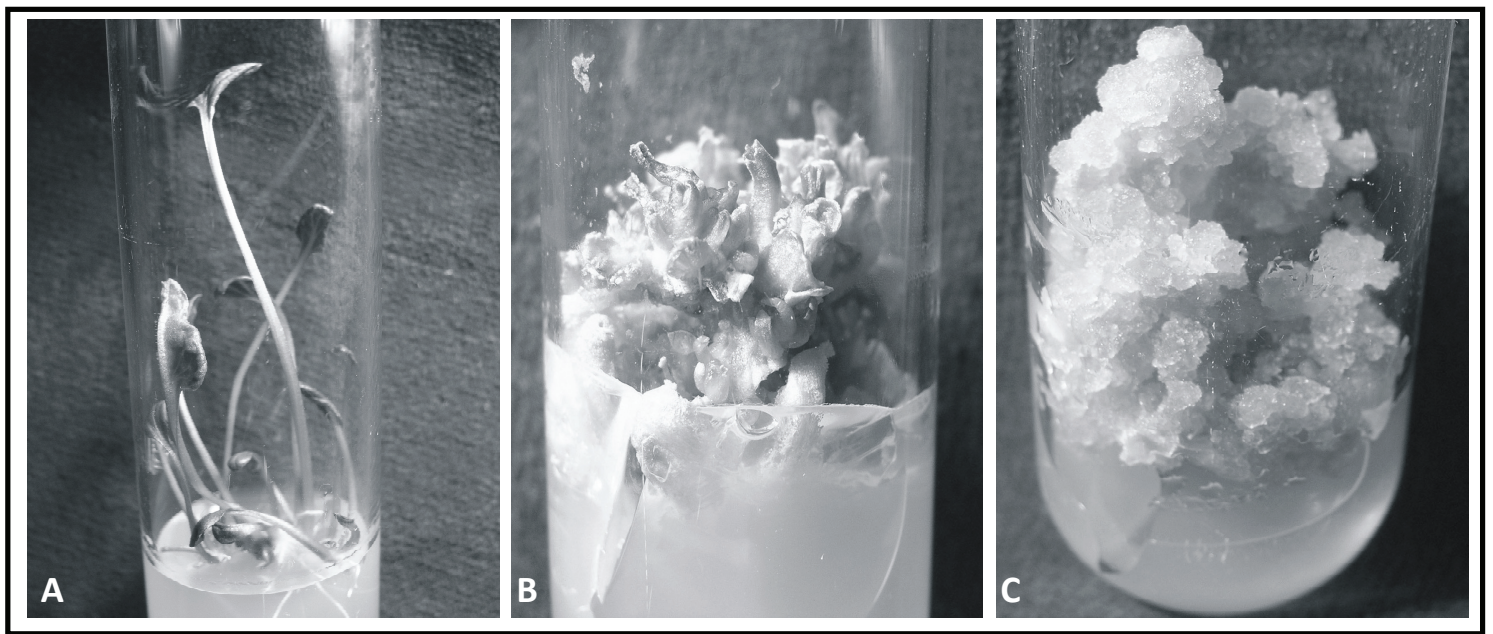

Figure 1. Armoracia lapathifolia Gilib. in vitro tissue culture: (A) horseradish plantlet; (B) teratoma tissue (TM); (C) tumor tissue (TN). 
malformed shoots with fleshy hyperhydrated leaves. These shoots have never developed roots but spontaneously formed unorganized tissue, which subsequently produced new shoots. The TN tumor line grew in an undifferentiated way, producing abundant yellow greenish unorganized tissue.

\section{Protein Extraction}

Soluble proteins were extracted from tissues in the exponential phase of growth ( 9 days after subculturing). Tissue samples were homogenized in the ice cold $100 \mathrm{mmol} \mathrm{\textrm {dm } ^ { - 3 }}$ Tris-HCl buffer $(\mathrm{pH} 8.0)$ containing sucrose $\left(\gamma=171 \mathrm{~g} \mathrm{dm}^{-3}\right)$, ascorbic acid $\left(\gamma=1 \mathrm{~g} \mathrm{dm}^{-3}\right)$ and cysteine-HCl $\left(\gamma=1 \mathrm{~g} \mathrm{dm}^{-3}\right)$. Tissue mass $(\mathrm{g})$ to buffer volume $(\mathrm{mL})$ ratio was $1: 5$ for leaves, $1: 1.2$ for TM and $1: 0.9$ for TN tissue. Insoluble polyvinylpyrrolidone (cca $50 \mathrm{mg}$ ) was added to each tissue sample prior to grinding in the mixer mill (MM200, Retsch, Germany) for $3 \mathrm{~min}$ at $30 \mathrm{~Hz}$. The homogenates were centrifuged $15 \mathrm{~min}$ at $20000 \mathrm{~g}$ and $4{ }^{\circ} \mathrm{C}$. The supernatants were ultracentrifuged at $120000 \mathrm{~g}$ and $4{ }^{\circ} \mathrm{C}$ for $90 \mathrm{~min}$. After ultracentrifugation $1.5 \mathrm{~mL}$ of the protein extracts was transferred to the centrifugal filter devices $\left(\right.$ Centricon $^{\circledR}, 10 \mathrm{MWCO}$, Millipore, USA) and centrifuged at $5000 \mathrm{~g}$ and $6{ }^{\circ} \mathrm{C}$ for $60 \mathrm{~min}$. The obtained filtrate was centrifuged again $10 \mathrm{~min}$ at $20000 \mathrm{~g}$ at $4{ }^{\circ} \mathrm{C}$. Supernatant was collected and protein content was determined according to Bradford ${ }^{24}$ using bovine serum albumin as a standard. Samples were denatured by heating in the Thermomixer (Eppendorf, USA) for $5 \mathrm{~min}$ at $96{ }^{\circ} \mathrm{C}$ using $125 \mathrm{mmol} \mathrm{dm}^{-3}$ Tris- $\mathrm{HCl}$ buffer ( $\mathrm{pH}$ 6.8) containing $\beta$-mercaptoethanol $(\varphi=5 \%)$ and sodium dodecyl sulphate (SDS) $\left(\gamma=20 \mathrm{~g} \mathrm{dm}^{-3}\right)$. For 1-DE 5-6 $\mu \mathrm{g}$ of proteins per sample was loaded onto the gel.

For 2-DE proteins were precipitated by the addition of 2 volumes of an ice-cold acetone. The mixture was left for minimum $120 \mathrm{~min}$ at $-20{ }^{\circ} \mathrm{C}$ and then centrifuged $15 \mathrm{~min}$ at $10000 \mathrm{~g}$. After centrifugation the pellet was air dried and dissolved in the sample buffer containing $9.5 \mathrm{~mol} \mathrm{dm}^{-3}$ urea, dithiotreitol (DTT, $\gamma=$ $\left.10 \mathrm{~g} \mathrm{dm}^{-3}\right)$, pharmalyte 3-10 $(\varphi=1 \%)$ and Triton $\mathrm{X}-100(\varphi=0.5 \%)$.

\section{1-DE and Lectin Assay}

Soluble cellular proteins were analyzed by $1-\mathrm{DE}$ in $12 \% \mathrm{~T}(2.67 \% \mathrm{C})$ polyacrylamide gels in a vertical electrophoresis system (Mini-PROTEAN 3 system, BioRad, USA) with the buffer system of Laemmli. ${ }^{25}$ The protein bands were visualized by silver staining ${ }^{26}$ and gels were scaned as an 8 bit grey scale Tiff-images with an HP Scanjet 2400 scanner (Hewlett-Packard Company, USA). Proteins were electroblotted to the nitrocellulose membrane (Pure nitrocellulose membrane - $0.2 \mu \mathrm{m}$, Bio-Rad, USA) in a Mini Trans-Blot Cell (Bio-Rad,
USA) at $60 \mathrm{~V}$ for $60 \mathrm{~min}$. The transfer buffer was $20 \mathrm{mmol} \mathrm{dm}{ }^{-3}$ Tris- $\mathrm{HCl}, 150 \mathrm{mmol} \mathrm{dm}{ }^{-3}$ glycine and methanol $(\varphi=10 \%)$. The membrane was stained with Ponceau-S stain (Roche Diagnostics, USA) to confirm the complete transfer of the proteins. The stain was washed off with distilled water. The unoccupied sites of the membrane were blocked by incubating the membrane with Tween ${ }^{\circledR} 20(\varphi=0.1 \%)$ (Sigma, USA) in TBS buffer, $\mathrm{pH} 7.5$ at $4{ }^{\circ} \mathrm{C}$ overnight.

Cellular glycoproteins were detected with Con A on 1-D protein blots. The bands and spots were visualized by peroxidase reaction using 4-chloro-1-naphthol as a substrate. ${ }^{27}$ The glycan part of proteins was further characterized according to binding of biotin- and digoxigenin-labeled lectins on 1-D protein blots. Applied digoxigenin-labeled lectins were GNA, MAA, DSA, PNA and SNA (DIG Glycan Differentiation Kit, Roche Diagnostics, USA). After the lectin treatment, membranes were incubated with anti-DIG conjugated with alkaline phosphatase. The bands were visualized by alkaline phosphatase reaction using NBT/BCIP as a substrate. Applied biotin-labeled lectins were UEA and $\mathrm{RCA}_{120}$ (Sigma, USA). The bands were visualized by streptavidine-alkaline phosphatase reaction using BCIP/NBT as a substrate. The binding specificity of each lectin is given in Table 1.

To avoid false positive reaction the following control glycoproteins were applied: the $63 \mathrm{kDa}$ glycoprotein, carboxypeptidase $\mathrm{Y}$, was used as a positive control for GNA and Con A and as a negative control for MAA, PNA, DSA, SNA, UEA and $\mathrm{RCA}_{120}$; the $80 \mathrm{kDa}$ glycoprotein, transferrin, was applied as a positive control for Con A, MAA, SNA and DSA and as a negative control for GNA, PNA, UEA and $\mathrm{RCA}_{120}$; the $65 \mathrm{kDa}$ glycoprotein, fetuin, was used as a positive control for MAA, DSA and SNA and as a negative control for Con A, GNA, PNA, UEA and $\mathrm{RCA}_{120}$; the $61 \mathrm{kDa}$ asialofetuin was applied as a positive control for PNA, SNA and $\mathrm{RCA}_{120}$ and as a negative control for Con A, GNA, MAA, DSA and UEA. For electroblotting $0.5 \mu \mathrm{g}$ of carboxypeptidase $\mathrm{Y}$, transferrin and fetuin and $2.5 \mu \mathrm{g}$ of asialofetuin was loaded onto the gel.

\section{2-DE and Electroblotting}

Dry non-linear immobilized $\mathrm{pH}$ gradient strips (IPG, $13 \mathrm{~cm}, \mathrm{pH}$ 3-10 NL, Pharmacia Biotech, Sweden) were rehydrated overnight in a rehydration buffer consisting of $8 \mathrm{~mol} \mathrm{dm}^{-3}$ urea, 3-[(3-cholamidopropyl)dimethylammonio]-1-propanesulfonate (CHAPS $\gamma=20 \mathrm{~g} \mathrm{dm}^{-3}$ ), pH 3-10 carrier ampholites $(\varphi=0.5 \%)$ and DTT $(\gamma=$ $\left.2 \mathrm{~g} \mathrm{dm}^{-3}\right)$ at room temperature. Proteins were subjected to isoelectric focusing (Multiphor II system, Pharmacia Biotech) for a total of $32000 \mathrm{Vh}$. The amount of $100 \mu \mathrm{g}$ of proteins per sample was loaded on each stripe. Immobiline dry strips were equilibrated $15 \mathrm{~min}$ in a 
Table 1. Major $N$ - and $O$-linked carbohydrate binding specificities of the different plant lectins applied

\begin{tabular}{|c|c|c|c|c|}
\hline $\begin{array}{c}\text { Taxonomic source of } \\
\text { lectin }\end{array}$ & Lectin & $\begin{array}{c}\text { Specificity toward carbohy- } \\
\text { drate moieties }\end{array}$ & $\begin{array}{l}\text { Type of } \\
\text { glycans }\end{array}$ & $\begin{array}{l}\text { Type of } \\
\text { labeling }\end{array}$ \\
\hline Canavalia ensiformis & Con A & $\begin{array}{c}\alpha-\mathrm{D}-\mathrm{Man} \\
\text { (inhibited by presence of } \\
\text { bisecting GlcNAc) }\end{array}$ & core $N$-glycan structure ${ }^{27}$ & digoxigenin \\
\hline Galanthus nivalis & GNA & $\begin{array}{l}\text { Man- } \alpha(1,3)-\text { Man } \\
\text { Man- } \alpha(1,6)-\text { Man }\end{array}$ & $\begin{array}{l}\text { terminal Man in high-mannose } \\
\text { and hybrid } N \text {-glycans }{ }^{27}\end{array}$ & digoxigenin \\
\hline Arachis hypogaea & PNA & Gal- $\beta(1,3)$-GalNAc & $\begin{array}{l}O \text {-glycosidically linked } \\
\text { carbohydrates }^{29}\end{array}$ & digoxigenin \\
\hline Datura stramonium & DSA & $\begin{array}{l}\text { Gal- } \beta(1,4)-G l c N A c \\
(\text { GlcNAc } \beta 1-4) \mathrm{n}\end{array}$ & $\begin{array}{l}\text { complex and hybrid } \\
N \text {-glycans } \\
{ }^{30}\end{array}$ & digoxigenin \\
\hline Maackia amurensis & MAA & NeuAc- $\alpha(2,3)-$ Gal & $\begin{array}{l}\text { sialic acid in complex } \\
N \text { - and } O \text {-glycans }\end{array}$ & digoxigenin \\
\hline $\begin{array}{l}\text { Sambucus } \\
\quad \text { nigra }\end{array}$ & SNA & NeuAc- $\alpha(2,6)-\mathrm{Gal}$ & $\begin{array}{l}\text { sialic acid in complex } \\
N \text { - and } O \text {-glycans }\end{array}$ & digoxigenin \\
\hline Ulex europaeus & UEA I & Fuc- $\alpha(1-2)-G a l$ & $\begin{array}{l}O \text {-glycosidically linked } \\
\text { carbohydrates }^{32}\end{array}$ & biotin \\
\hline Ricinus communis & $\mathrm{RCA}_{120}$ & Gal- $\beta(1,4)-$ GlcNAc & $\begin{array}{l}\text { complex and hybrid } \\
N \text {-glycans }\end{array}$ & biotin \\
\hline
\end{tabular}

buffer containing $6 \mathrm{~mol} \mathrm{dm}^{-3}$ urea, glycerol $(\varphi=30 \%)$, $\operatorname{SDS}\left(\gamma=20 \mathrm{~g} \mathrm{dm}^{-3}\right)$ with DTT $\left(\gamma=20 \mathrm{~g} \mathrm{dm}^{-3}\right)$ and then $15 \mathrm{~min}$ in the same buffer with iodoacetamide $(\gamma=$ $\left.25 \mathrm{~g} \mathrm{dm}^{-3}\right)$. The second dimension was a vertical SDSPAGE (Protean II xi cell, Bio-Rad, USA) in $12 \% \mathrm{~T}$ $\left(2.67 \%\right.$ C) gels using the buffer system of Laemmli. ${ }^{25}$ Protein spots were silver stained. ${ }^{26}$ The stained gels were scanned as a 8 bit grey scale Tif-images with a HP Scanjet 2400 scanner (Hewlett-Packard Company, USA). Proteins were transferred to a nitrocellulose membrane using the semi-dry electroblotter equipment (Multiphor II system, Pharmacia Biotech) (60 min, $150 \mathrm{~mA}$ ). The anodic transfer buffer was $48 \mathrm{mmol} \mathrm{dm}^{-3}$ Tris-HCl, $39 \mathrm{mmol} \mathrm{dm}{ }^{-3}$ glycine, $1.3 \mathrm{mmol} \mathrm{dm}^{-3} \mathrm{SDS}$ and methanol $(\varphi=20 \%)$, while the cathodic transfer buffer was of the same composition but devoid of methanol. The membrane was treated as it was previously described and cellular glycoproteins were detected with ConA.

\section{Image Analysis of 2-D Gels}

Image analysis was carried out with ImageMaster 2D Platinum software version 7.0 (GE Healthcare, USA) which allows spot detection, quantification, background subtraction and spot matching among multiple gels. Each plant material was analyzed in biological triplicate. To compensate for subtle differences in sample loading, gel staining and destaining, the volume of each spot was normalized as a relative volume. This normalization method provided by ImageMaster 2D Platinum software divides each spot volume value by the sum of total spot volume values to obtain individual relative spot volumes. Total spot volume refers to the sum volume of all spots chosen for analysis; therefore, the volumes of spots excluded from the analysis were not considered. After spot detection, quantification, and background subtraction, each analyzed gel was matched individually to the reference gel, and matched spots were grouped into subclasses. The relative volumes for a particular spot, obtained from at least three biological analyses, were averaged. Finally, the relative abundance of particular matched spot was calculated as a ratio of average relative spot volume of transformed tissue (TM or TN) and average relative spot volume of leaf (L).

\section{MS Analysis}

Protein spots were excised with a pipette tip from the gel and destained by mixture of $30 \mathrm{mmol} \mathrm{dm}^{-3}$ potassium hexacyanoferrate (II) and $100 \mathrm{mmol} \mathrm{dm}^{-3}$ sodium disulfate $(1: 1)$. After trypsin in-gel digestion (Roche, US), peptides were purified using ZipTip C4 (Millipore, USA) and dried. Obtained tryptic peptides were resuspended in $5 \mu \mathrm{l}$ of $5 \mathrm{mg} \mathrm{mL}^{-1} \alpha$-cyano-4-hydroxycinnamic acid (CHCA) matrix prepared in aqueous solution containing acetonitrile $(\varphi=50 \%)$ and spotted onto the MALDI plate. All the chemicals were purchased from Merck, Germany unless specifically indicated.

Mass spectra were obtained using matrix-assisted laser desorption/ionization-time-of-flight mass spectrometer (4800 Plus MALDI TOF/TOF analyzer, Applied Biosystems, USA) in positive reflector mode. For each spot, 1600 shots per spectrum were taken covering the mass range of $800-4000 \mathrm{Da}$, focus mass $2000 \mathrm{Da}$ and delay time $500 \mathrm{~ns}$. Trypsin autolysis peaks were used as internal standards. Automated spectrum interpretation was performed, choosing ten most intense peaks of each MS spectrum (excluding peaks generating from trypsin autolysis, matrix or acrylamide) for subsequent MS/MS analysis. MS/MS was achieved by $1 \mathrm{kV}$ collision-induced dissociation (CID). Proteins were identified by applying Global Protein Server (GPS) Explorer software (version 3.6, Applied Biosystems, 
USA) for Mascot (Matrix Science, UK) search against SwissProt database. Monoisotopic peptide masses were used for combined MS and MS/MS database searches considering up to four missed cleavages, oxidation of methionine, monoisotopic peptide mass tolerance of $21 \mathrm{ppm}$ and fragment ion mass tolerance of 0.2 Da.

\section{RESULTS}

\section{1-D Protein Pattern}

Few tissue specific proteins were detected by 1-DE (Figure 2). The 22, 23, 24, 25 and $110 \mathrm{kDa}$ polypeptides (white arrows) were specific for leaf extract. In TM and TN tissues some distinct polypeptides of 33, 35 and 115 (asterisks) as well as several bands in the range from 95 to $100 \mathrm{kDa}$ (bracket) were present, which were not detected in the leaf. The bands of 64 and $65 \mathrm{kDa}$ were remarkable in TN tissue only (circle). The 15 and $54 \mathrm{kDa}$ polypeptides, most likely subunits of Rubisco, as well as the $37 \mathrm{kDa}$ polypeptide (rectangles) were present in all samples, although they were quantitatively dominant in the leaf. Furthermore, the 27 and $28 \mathrm{kDa}$ polypeptides (white dots) were quantitatively dominant in TN tissuse, while the $26 \mathrm{kDa}$ polypeptide was predominant in TM tissue (black dot). All examined tissues expressed the 16, 39, 40, 43, 53, 60, 75 and $80 \mathrm{kDa}$ polypeptides (stars), although they were more intensive in TM and TN tissues in comparison to leaf.

\section{1-D Glycoprotein Pattern}

After 1-DE, proteins were blotted onto a nitrocellulose membrane to detect tissue specific glycoproteins by means of application of different lectins. The Con A and GNA lectins crossreacted with glycoproteins of 43 and $66 \mathrm{kDa}$, expressed in all samples, although with different intensities (Figure 3A, B). The $66 \mathrm{kDa}$ glycoprotein (Figure 3A, B; black arrows) was highly expressed in the leaf, while the $43 \mathrm{kDa}$ glycoprotein predominated in TM tissue (Figure 3A, B; grey arrows). The $45 \mathrm{kDa}$ band detected with GNA was present only in the leaf and TM tissue (Figure 3B; arrow head). MAA and PNA lectins exhibited similar glycoprotein patterns; the 18, 30 and $45 \mathrm{kDa}$ glycoproteins reacted with both abovementioned lectins in all tissues (Figure 3C, D; asterisks), the 23, 28 and $67 \mathrm{kDa}$ ones (black arrows) gave positive reaction with PNA and MAA only in TM and TN tissues, while the bands of 19, 20, 24, 25 and $46 \mathrm{kDa}$ (arrow heads) were specific for TN tissue only. PNA revealed some additional bands of $47 \mathrm{kDa}$ (black dot) in leaf and TM tissue as well as $44 \mathrm{kDa}$ (black square) in TM tissue. DSA lectin reacted with the $27 \mathrm{kDa}$ glycoprotein (Figure 3E; arrow) in TM and TN, while SNA gave positive reaction with the same protein in all three tissues (Figure 3F; arrow). Lectins UEA and $\mathrm{RCA}_{120}$ revealed only one glycoprotein of $70 \mathrm{kDa}$ (Figure $3 \mathrm{G}$, $\mathrm{H}$; arrows), which was expressed in all samples.

\section{2-D Protein and Glycoprotein Pattern}

Image Master 2D Platinum software detected the total of 265 protein spots, which were grouped according to their appearance in the certain tissue(s). Ten groups of proteins were common for all investigated tissues (Figure 4 , circles 1-10). In addition, leaf extract revealed six protein groups (Figure 4A, squares 11-14 and 17-18), which were characteristic for this tissue, although it shared certain proteins with TM (Figure 4A, B; squares 15 and 16). In both transformed horseradish tissues two common protein groups were found (Figure 4B, C; squares 20 and 21), though TM and TN also showed some specific proteins (Figure 4B, C; squares 22-24, and 25-27, respectively).

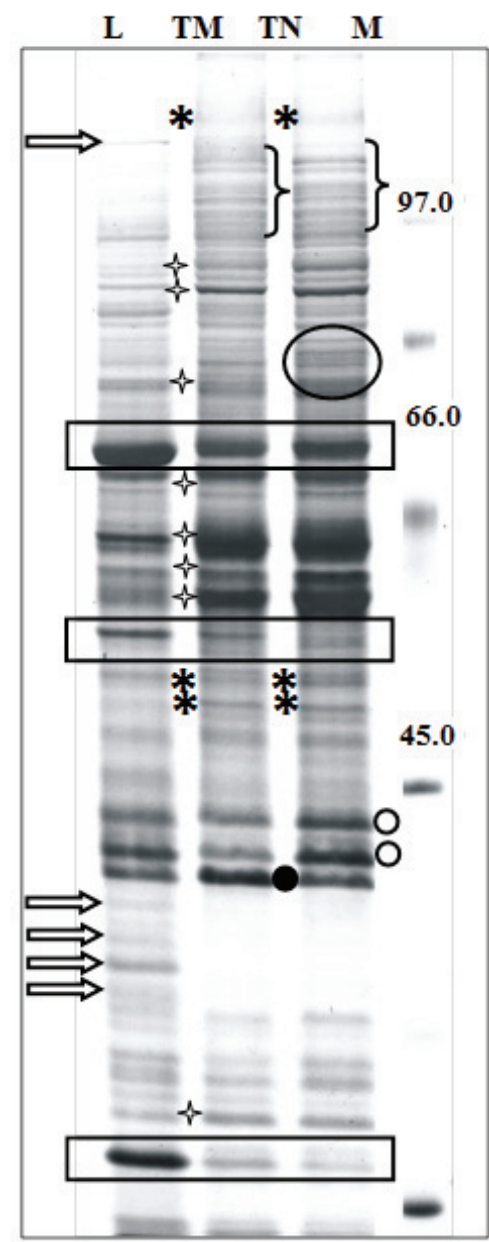

Figure 2. 1-DE pattern of soluble cellular proteins. Proteins were separated in $12 \%$ gel and silver stained. Lanes: L, leaf; TM, teratoma tissue (TM); TN, tumor tissue (TN); M, molecular mass marker $(\mathrm{kDa})$. 


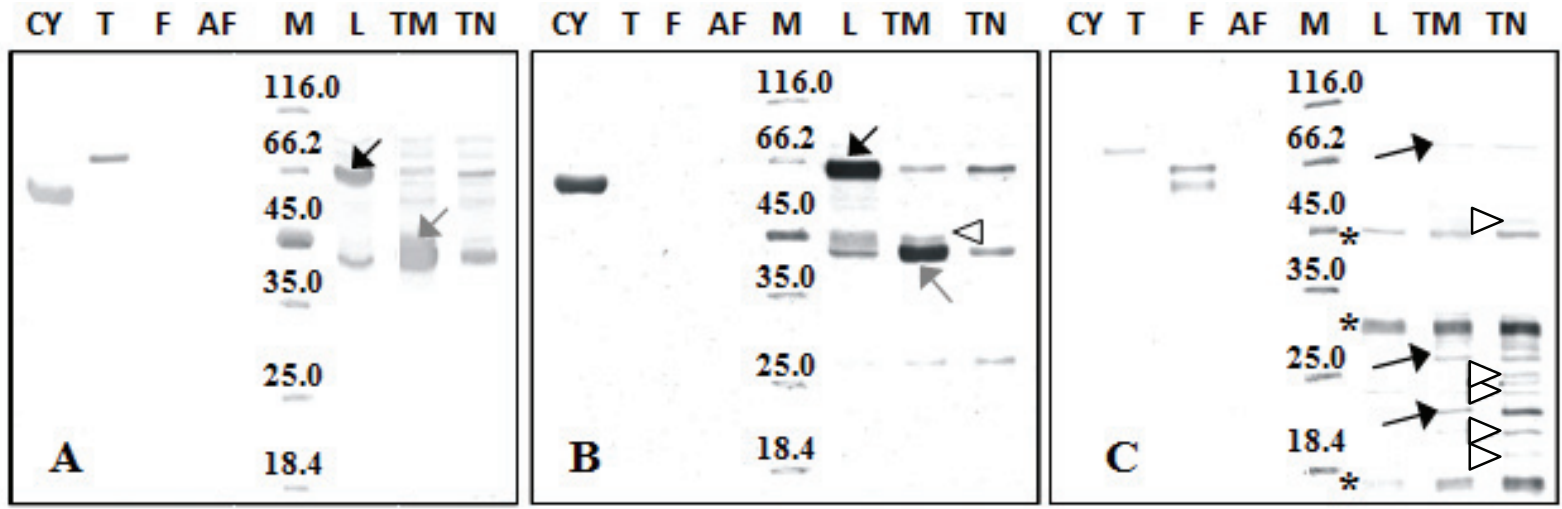

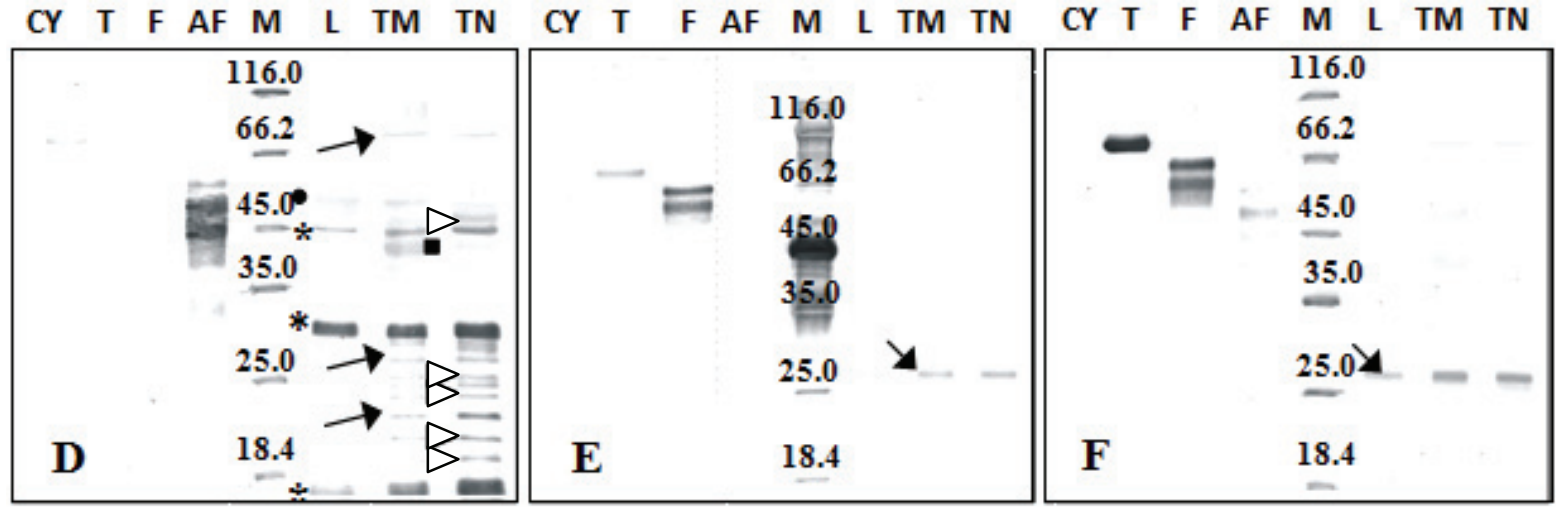

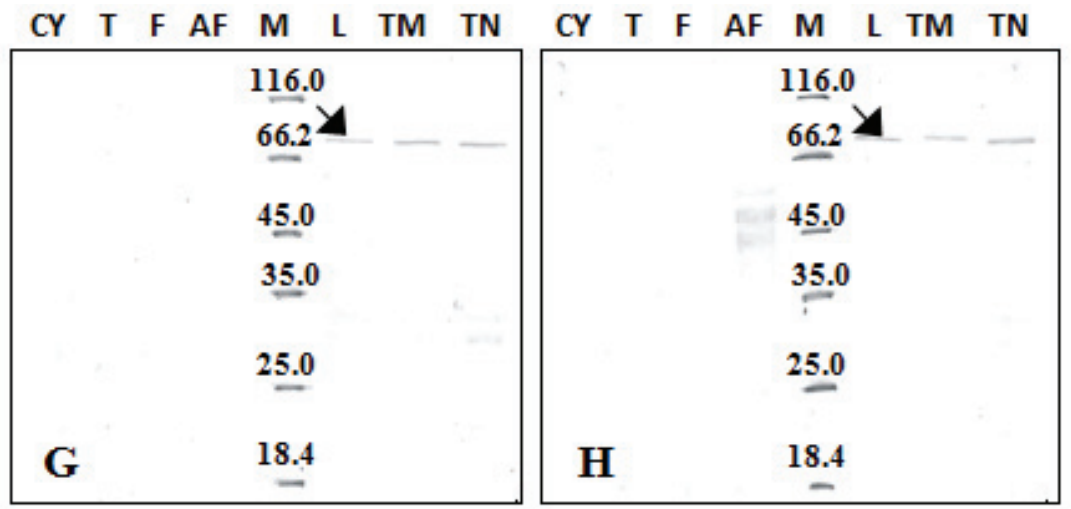

Figure 3. Glycoprotein pattern after 1-DE and transfer onto a nitrocellulose membrane according to binding of following lectins: (A) Con A; (B) GNA; (C) MAA; (D) PNA; (E) DSA; (F) SNA; (G) UEA and (H) RCA 120. Lanes: CY, control glycoprotein carboxypeptidase $\mathrm{Y} ; \mathrm{T}$, control glycoprotein - transferring; $\mathrm{F}$, control glycoprotein - fetuin; AF, control glycoprotein asialofetuin; M, molecular mass marker (kDa); L, leaf; TM, teratoma tissue (TM); TN, tumor tissue (TN).

The proteins separated by 2-DE were transferred onto a nitrocellulose membrane to detect the glycosylated proteins crossreacting with Con A (Figures 4D-F). The glycoprotein group, assigned as group 1 on 2-D gels, was common for all tissues and consisted of several glycosylated spots of approximately $43 \mathrm{kDa}$ which moved in an IEF with pI value of 8-9 (Figures 4D-F, circle 1); the strongest expression of this group was detected in TM tissue. Horseradish leaf was characterized by the presence of additional glycoproteins which, according to their molecular weight and pI value, corresponded to protein groups assigned as 9, 12, 15 and 18 on 2-D gels (Figure 4A, D; circle 9 and squares 12, 15 and 18). The greatest number of glycoproteins was found in TM tissues in which, beside the strong expression of group 1, several other glycosylated proteins were detected; several belonged to the common protein groups detected on 2-D gels (Figure 4B, E; circles 3-5, 10), while two of them were characteristic for TM only (Figure 4B, E; squares 19 and 22). 


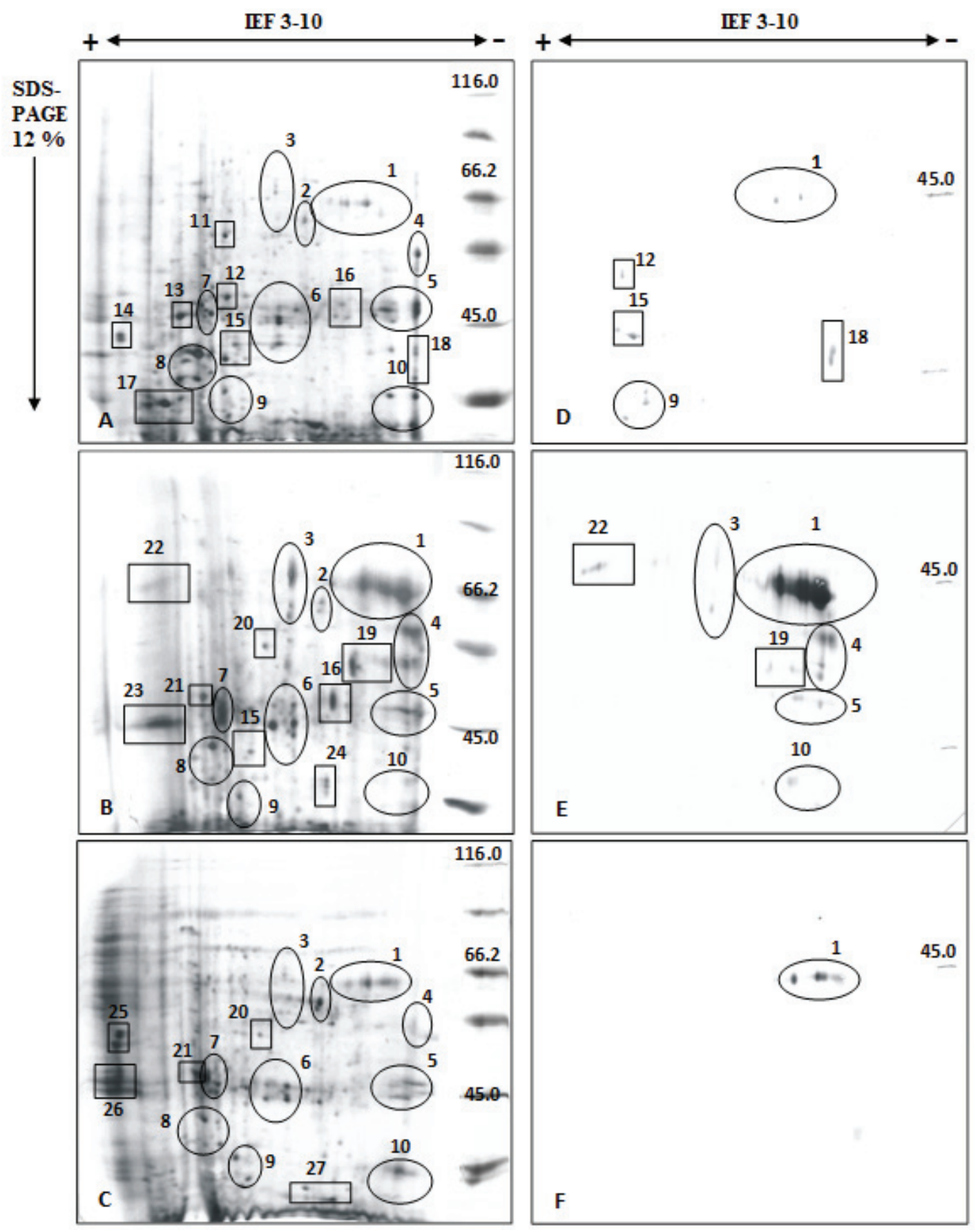

Figure 4. Silver stained 2-D gels of soluble cellular proteins: (A) leaf (L); (B) teratoma tissue (TM); (C) tumor tissue (TN); (D), (E) and (F) - corresponding electroblots showing glycoproteins which crossreacted with Con A and were visualized by peroxidase reaction. The circles indicate protein and glycoprotein groups common for all tissues, while squares indicate protein and glycoprotein groups characteristic for certain tissue(s).

\section{MS Analysis}

Three protein spots which exhibited the most prominent difference in ConA-signal obtained on 2D-blot, assigned as group 1 on the 2-D gels (Figures 4 and 5A) were chosen for MS analysis. Out of these three spots (Figure
5A; spots No. 1, 2 and 3), only spot assigned as spot No. 2 was successfully identified. Mass spectrometry analysis identified this protein as a typical horseradish peroxidase (Table 2). The abundance of the identified HRP was 6 times higher in TM and 2 times higher in TN compared to L (Figure 5C). 
$\mathbf{A}$

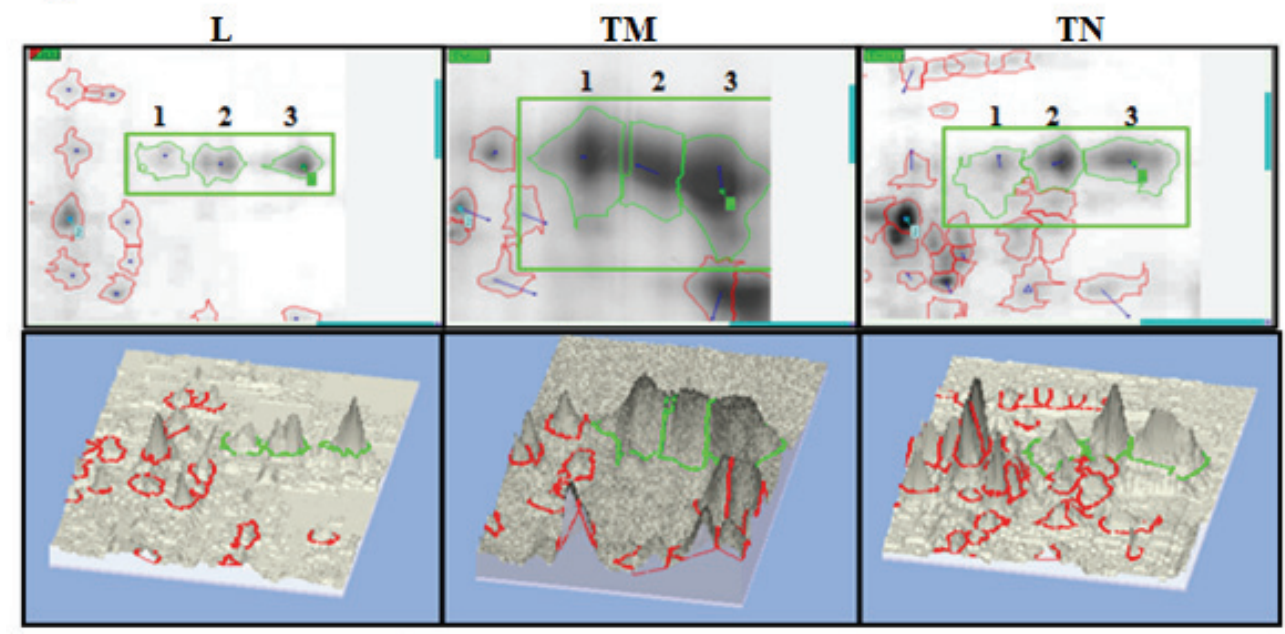

\begin{tabular}{cccc} 
B & \multicolumn{3}{c}{} \\
\hline & Average of $\%$ & $V$ for particular spot \\
\hline & Spot No. 1 & Spot No. 2 & Spot No. 3 \\
\hline $\mathrm{L}$ & 0.255 & 0.548 & 0.567 \\
$\mathrm{TM}$ & 3.643 & 3.374 & 4.722 \\
$\mathrm{TN}$ & 0.782 & 1.169 & 1.804 \\
\hline
\end{tabular}

C

\begin{tabular}{|c|c|c|c|}
\hline & \multicolumn{3}{|c|}{ Abundance of particular spot } \\
\hline & Spot No. 1 & Spot No. 2 & Spot No. 3 \\
\hline $\mathrm{TM} / \mathrm{L}$ & 14.286 & 6.157 & 8.328 \\
\hline $\mathrm{TN} / \mathrm{L}$ & 3.067 & 2.133 & 3.182 \\
\hline
\end{tabular}

Figure 5. (A) Representation of spot matching and 3D-view of 3 protein spots from the glycoprotein group, assigned as group 1 on the 2D gels, using ImageMaster Platinum software version 7.0; (B) For quantification three biological replicates for each plant material were analyzed. Spots from analyzed gels were matched with spots from reference gel and average relative volume $(\% \mathrm{~V})$ for matched spots was obtained; (C) Calculation of abundance of particular matched spot as a ratio of transformed tissue (TM or $\mathrm{TN}$ ) average relative spot volume and $\mathrm{L}$ average relative spot volume. L, leaf; TM, teratoma tissue (TM); TN, tumor tissue (TN).

\section{DISCUSSION}

Despite obvious morphological differences between horseradish plants and transformed tissues, only few morphogenesis-specific cell polypeptides were observed by 1 -DE. Leaf extracts were characterized by five protein bands that were not detected in TM and TN tissues, which however also exhibited some distinctive protein markers. In general, differences in protein pattern between examined tissues were more quantitative than qualitative. For example, 15 and $54 \mathrm{kDa}$ polypeptides, most likely subunits of Rubisco, were present in all tissues, although quantitatively lower in TM and TN, probably as a consequence of chloroplasts dedifferentiation toward proplastids and low total chlorophyll content with reduced photosynthetic activity found in these transformed tissues (Peharec Štefanić et al., unpublished data). Similar differences obtained in 1-D protein pattern were also reported for in vitro grown cactus tissues of different organization level. ${ }^{8}$

In the search for a more reliable molecular marker of in vitro morphogenesis, 2-DE was applied since this technique has a higher resolving power for separation of complex mixtures of heterogenous polypeptides than 1-DE. However, only a few studies on morphology of different plant tissues have used 2-DE in order to separate cellular polypeptides on the basis of both their molecular weight and their isoelectric point. ${ }^{8,11,34}$ In the present study, 2-DE revealed more differences in protein expression between examined tissues in comparison to 1-DE: ten groups of proteins were common for all tissues, while numerous spots characteristic of each

Table 2. Identified protein after 2-DE and SwissProt database search analysis

\begin{tabular}{cccccc}
\hline Spot No. & Protein & Accession No. & $\begin{array}{c}\text { Protein } \\
\text { score }^{(a)}\end{array}$ & Peptide count & $\begin{array}{c}\text { Sequence } \\
\text { coverage }\end{array}$ \\
\hline 2 & $\begin{array}{c}\text { Peroxidase } \\
\text { C1C }\end{array}$ & P15233 PER1C_ARMRU & 63 & 10 & $37 \%$ \\
\hline
\end{tabular}

(a) The statistical significance threshold for reporting matches against database sequences (> 56). 
tissue line were found. Interestingly, partially organized TM teratoma tissue shared two groups of proteins with either fully organized horseradish leaf as well as with completely unorganized TN tumour, which indicates that tissue morphology could be reflected in 2-D pattern of horseradish cellular proteins. However, further studies should identify some of the detected proteins and determine their localisation, modifications, interactions, activities, and ultimately their function.

Glycosylation is a crucial event dominating postor co-translational modifications of $>50 \%$ of eukaryotic proteins. ${ }^{28}$ In addition, there are evidences that glycan structures reflect their evolutionary backgrounds and functional aspects in various contexts, including differentiation, development, fertilization, inflammation, cell adhesion and cell-cell recognition. ${ }^{35}$ The new concept of glycomics has been proposed as the third class of biologically inherited, informative macromolecules, together with nucleic acids and proteins. Extensive research has been carried out on both structural and functional aspects of glycans. ${ }^{36}$ One way to facilitate structural glycomics is "lectin-based glycan profiling", the essence of which is to extract core information (for example, $\mathrm{N}$-glycosylated or $\mathrm{O}$-glycosylated, highmannose type or complex type, core-fucosylated or not, fully or partially sialylated and other information) about glycan structures by means of lectin affinity technologies. ${ }^{33}$ The use of lectins in glycan profiling provides considerable advantages, such as discrimination between the isomers on the basis of biological rather than physicochemical principles. ${ }^{28}$ Lectin-based glycan profiling has already been successfully applied in several plant glycoprotein studies. ${ }^{9,27,37,38}$ In the present study this type of glycan analysis was employed to investigate whether the morphological differences between different horseradish tissues cultivated in vitro were reflected in glycosylation profile of cellular soluble proteins. Con A and GNA, which specifically bind to $N$-glycosylated proteins, revealed very similar pattern. The 43 glycoprotein gave the strongest expression in TM. MAA and PNA revealed almost the same glycoprotein pattern and the highest number of cellular glycoproteins in all horseradish tissue, although both TM and TN were particularly rich in glycoproteins detected with these lectins in comparison to L. Since MAA specifically binds to NeuAc $\alpha(2,3)$ linked to Gal and PNA recognizes disaccharide Gal- $\beta(1,3)$-GalNAc, this result indicates the high content of sialylated $O$-glycoproteins in both tissues. However, result obtained with DSA and SNA revealed also the presence of $N$-glycosylated protein with terminal NeuAc $\alpha(2,6)$ linked to Gal. Sialic acid is a common glycan found on animal glycoproteins, but controversial in plants. ${ }^{39,40}$ Sialylated glycoconjugates have been reported in suspensioncultured cells of Arabidopsis thaliana, ${ }^{31}$ in cellular and extracellular proteins of sugar beet tissue lines $^{9}$ as well as in cellular glycoproteins of Mammillaria gracilis grown in vitro ${ }^{10,38}$ which proves that a genetic and enzymatic basis for sialylation exits in plants. Moreover, enhanced sialylation of human and animal tumor tissues has been widely reported, ${ }^{41,42}$ which is in agreement with our results, since both TM and TN tissues are considered as plant tumors obtained by transformation with A. tumefacines. In all horseradish tissues $\mathrm{RCA}_{120}$ detected the $70 \mathrm{kDa}$ protein, which demonstrates the presence of the Gal- $\beta(1-4)-G l c N A c$ sequence in complex and hybrid $\mathrm{N}$-glycans. The same band was also detectable with UEA, a lectin that binds to $O$-glycosidically linked carbohydrates, which suggests that this protein might posses both $\mathrm{N}$ - and $\mathrm{O}$-glycosylation sites, although $\mathrm{RCA}_{120}$ and UEA may alternatively recognize different glycoproteins of similar molecular size, which are not resolved by 1 -DE. Balen et al. ${ }^{37}$ reported similar findings for glycoproteins of $M$. gracilis tissues grown in vitro.

2-DE and electroblotting revealed that all horseradish tissues were characterized by the presence of group 1 of glycoproteins, although the staining intensity was more pronounced in TM tissue. These data support results obtained with Con A and GNA on 1-D membranes, where the $43 \mathrm{kDa}$ glycoprotein also predominated in TM tissue. Data obtained by mass spectrometry analysis identified one of the proteins from the group 1 as a typical horseradish peroxidase (HRP), which is in accordance with the highest peroxidase activity measured in this tissue. ${ }^{20}$ In its native form, HRP is a glycoprotein with nine potential $\mathrm{N}$-glycosylation sites and a carbohydrate content of approximately $20 \%$ of the total mass. The dominant oligosaccharide present on HRP is a trimannosyl $N$-glycan with $\beta(1,2)$-linked $\mathrm{Xyl}$ and $\alpha(1,3)$-linked Fuc core modifications typically found in plants, but many other $N$-glycan structures of the general formula Man2-7GlcNAc2-3Fuc0-1Xy10-1 have been detected in minor amounts. ${ }^{43}$ The quantitative difference in expression of HRP, detected on both 1-D and 2-D blots, suggests that this particular glycoprotein is subdued to changes in glycosylation during the course of tumorization and should be further explored as a potential marker of morphogenesis. In $\mathrm{L}$ tissue some discrepancies in glycoprotein pattern obtained with Con A were observed between 1-D and 2-D blots. Namely, 2-D blots were devoid off $66 \mathrm{kDa}$ glycoprotein, but at the same time revealed a few glycoproteins of lower molecular weight (groups 9 and 18). These differences could be a consequence of different types of blotting performed after 1-DE (wet blotting) and 2-DE (semi-dry blotting), respectively. Interestingly, both $\mathrm{L}$ and $\mathrm{TM}$ revealed glycosylation of certain proteins that belonged to the groups which were common for all horseradish tissues, but were detected as glycoproteins in either 
L (group 9) or TM (35 and 10). These results suggest that one particular protein, although present in all investigated tissues, could have tissue specific sugar composition, therefore the variations of $\mathrm{N}$-glycan moiety of the same protein can be related to the specific morphogenesis of plant tissue. The highest number of glycoprotein spots was detected in partially organized TM, while the completely unorganized TN revealed only one group of glycoproteins, which was common for all horseradish tissues. This result is contrary to the highest number of glycosylated proteins on 2-D blots reacting with Con A found in completely unorganized tumor tissue of cactus grown in vitro, ${ }^{11}$ which only suggests that glycosylation pattern is not only dependent on tissue morphology but on the plant species as well.

\section{CONCLUSION}

1-DE glycoprotein pattern screening performed by lectin affinity blotting showed substantial differences between horseradish tissues of different morphologies. However, this result was in the contrast to silver stained protein profiles, where only slightly qualitative changes were observed, which implies that the oligosaccharide structures could be important determinants of specificities of horseradish tissue morphology. 2-DE, a more powerful protein separation technique, revealed more differences in expression of cellular proteins between examined tissues in comparison to 1-DE. Moreover, 2-DE blots confirmed quantitative difference in expression of $43 \mathrm{kDa}$ glycoprotein, identified as HRP, between investigated tissues. This suggests that HRP is subdued to changes in glycosylation during the course of tumorization and should be further explored as a potential marker of morphogenesis in horseradish tissue culture.

Acknowledgements. The financial support of this work was provided by The Ministry of Science, Education and Sports of the Republic of Croatia within the project 119-1191196-1200.

\section{REFERENCES}

1. C. T. Walsh, S. Garneau-Tsodikova, and G. J. Gatto, Angew. Chem. Int. Ed. 44 (2005) 7342-7372.

2. B. Küster, S. F. Wheeler, A. P. Hunter, R. Dwek, and D. J. Harvey, Anal. Biochem. 250 (1997) 82-101.

3. M. Krsnik-Rasol and B. Balen, Food Technol. Biotechnol. 45 (2007) $1-10$

4. M. Krsnik-Rasol, H. Čipčić, D. Poljuha, and D. Hagége, Phyton 41 (2000) 13-20.

5. L. H. Stevens, G. M. Stoopen, I. J. Elbers, J. W. Molthoff, H. A. C. Bakker, A. Lommen, D. Bosch, and W. Jordi. Plant Physiol. $124(2000)$ 173-182.

6. I. J. W. Elbers, G. M. Stoopen, H. Bakker, L. H. Stevens, M. Bardor, J. W. Molthoff, W. J. R. M. Jordi, D. Bosch, and A. Lommen, Plant Physiol. 126 (2001) 1314-1322.

7. D. C. Andersen and C. F. Goochee, Curr. Opin. Biotechnol. 5 (1994) 546-549.
8. B. Balen, J. Milošević, and M. Krsnik-Rasol, Food Technol. Biotechnol. 40 (2002) 275-280.

9. D. Pavoković, I. Šola, D. Hagége, and M. Krsnik-Rasol, Acta Bot. Croat. 66 (2007) 127-134.

10. B. Balen, A. Zamfir, S. Y. Vakhrushev, M. Krsnik-Rasol, and J. Peter-Katalinić, Croat. Chem. Acta 78 (2005) 463-477.

11. B. Balen, M. Krsnik-Rasol, A. D. Zamfir, J. Milošević, S. Y. Vakhrushev, and J. Peter-Katalinić, J. Proteome Res. 5 (2006) $1658-1666$.

12. P. Van den Steen, P. M. Rudd, R. A. Dwek, and G. Opdenakker, Crit. Rev. Biochem. Mol. 33 (1998) 151-208.

13. V. Gomord, A. C. Fitchette, L. Menu-Bouaouiche, C. Saint-JoreDupas, C. Plasson, D. Michaud, and L. Faye, Plant Biotechnol. $J .8(2010) 564-587$.

14. K. L. Johnson, B. J. Jones, A. Bacic, and C. J.Schultz, Plant Physiol. 133 (2003) 1911-1925.

15. M. Kreuger and G. J. Holst, Plant Mol. Biol. 30 (1996) $1077-$ 1086.

16. A. Chapman, A. S. Blervacq, J. Vasseur, and J. L. Hilbert, Planta 211 (2000) 305-314.

17. A. Paire, P. Devaux, C. Lafitte, C. Dumas, and E. MatthysRochon, Plant Cell Tiss. Organ. Cult. 73 (2003) 167-176.

18. G. Borderies, M. Le Béchec, M. Rossignol, C. Lafitte, E. Le Deunff, M. Beckert, C. Dumas, and M. R. Elisabeth, Eur. J. Cell Biol. 83 (2004) 205-212.

19. S. M. Velasquez, M. M. Ricardi, J. Gloazzo Dorosz, P. V. Fernandez, A. D. Nadra, L. Pol-Fachin, J. Egelund, S. Gille, J. Harholt, M. Ciancia, H. Verli, M. Pauly, A. Bacic, C. E. Olsen, P. Ulvskov, B. L. Petersen, C. Somerville, N. D. Iusem, and J. M. Estevez, Science 332 (2011) 1401-1403.

20. B. Balen, D. Pavoković, P. Peharec, and M. Krsnik-Rasol, Sci. Hort. 119 (2009) 88-97.

21. M. Krsnik-Rasol and J. Muraja-Fras: Peroxidase as a morphogenesis marker in horse-radish crown gall tissue. in: K.G. Welinder, S.K. Rasmussen, C. Penel, H. Greppin (Eds.) Plant Peroxidases Biochemistry and Physiology, University of Geneva, Geneva, Switzerland, 1993, pp. 423-428.

22. T. Peškan, M. Ćurković Perica, and M. Krsnik-Rasol, Plant Physiol. Biochem. 34 (1996) 385-391.

23. T. Murashige and F.Skoog, Plant Physiol. 15 (1962) 473-497 .

24. M. M. Bradford, Anal. Biochem. 72 (1976) 248-254.

25. U. K. Laemmli, Nature 227 (1970) 680-685.

26. H. Blum, H. Beier, and H. J. Gross, Electrophoresis 8 (1987) 9399

27. P. Hrubá and J. Tupý, Plant Sci. 141 (1999) 29-40.

28. A. Kuno, N. Uchiyama, S. Koseki-Kuno, Y. Ebe, S. Takashima, M. Yamada, and J. Hirabayashi, Nature Methods 2 (2005) 851856.

29. C. Mérant, A. Messouak, J. L. Cadoré, and J. C. Monier, Glycoconj. J. 22 (2005) 27-34.

30. K. Yamashita, K. Totani, T. Ohkura, S. Takasaki, I. J. Goldstein, and A. Kobata, J. Biol. Chem. 262 (1987) 1602-1607.

31. M. M. Shah, K. Fujiyama, C. R. Flynn, and L. Joshi, Nature Biotechnol. 21 (2003) 1470-1471.

32. S. Kimura, M. Yamada, I. Igaue, and T. Mitsui, Plant Cell Physiol. 34 (1993) 855-863.

33. J. Hirabayashi, Glycoconj. J. 21 (2004) 35-40.

34. D. Pavoković, D. Poljuha, A. Horvatić, N. Ljubešić, D. Haège, and M. Krsnik-Rasol, Plant Cell Tiss. Organ Cult. 108 (2012) 111-119.

35. T. Feizi, Glycoconj. J. 17 (2000) 553-565.

36. J. Hirabayashi and K. Kasai, Trends Glycosci. Glycotechnol. 12, (2000) $1-5$.

37. B. Balen, M. Krsnik-Rasol, A. D. Zamfir, I. Zadro, S. Y. Vakhrushev, and J. Peter-Katalinić, J. Biomol. Tech. 18 (2007) 150-160.

38. B. Balen, P. Peharec, and M. Krsnik-Rasol, Acta Bot. Croat. 67 
(2008) 221-227.

39. M. Seveno, M. Bardor, T. Paccalet, V. Gomord, P. Lerouge, and L. Faye, Nat. Biotech. 22 (2004) 1351-1352.

40. Z. Reinhard, K. Daniel, S. Richard, and A. Friedrich, Planta 224, (2006) 222-227.
41. E. Dabelsteen, J. Pathol. 179 (1996) 358-69.

42. P.-H. Wang, J. Cancer Mol. 1 (2005) 73-81.

43. M. Wuhrer, C. I. A. Balog, C.A. M. Koeleman, A. M. Deelder, and C. H. Hokke, Biochim. Biophys. Acta 1723 (2005) 229-239. 